\title{
Effect of Tulsi (Ocimum sanctum) Leaf and Ginger (Zingiber officinale) Powder as Feed Additives on Haemato-biochemical Parameters of Broiler Chicks
}

\author{
Kavita Shende $^{1^{*}}$, Rajesh Kumar Dhuria ${ }^{2}$, Deepika Goklaney ${ }^{3}$ and Yogesh Kumar Barolia ${ }^{4}$ \\ ${ }^{1}$ Department of Animal Nutrition, CVAS, Navania, Vallabhnagar, Udaipur, Rajasthan University of Veterinary E Animal \\ Sciences, Bikaner, Rajasthan, INDIA \\ ${ }^{2}$ Department of Animal Nutrition, CVAS, Bikaner, Rajasthan University of Veterinary \& Animal Sciences, Bikaner, \\ Rajasthan, INDIA \\ ${ }^{3}$ Department of Veterinary Medicine, CVAS, Bikaner, Rajasthan University of Veterinary \& Animal Sciences, Bikaner, \\ Rajasthan, INDIA \\ ${ }^{4}$ Department of Animal Husbandry, Udaipur, Rajasthan, INDIA \\ *Corresponding author: K Shende; E-mail: dr.kavitashende@gmail.com
}

Received: 26 Sept., 2020

Revised: 15 Dec., 2020

Accepted: 16 Dec., 2020

\begin{abstract}
The objective of the study was to evaluate the effect of tulsi and ginger as feed additives on haemato-biochemical parameters of broiler chicks. Two hundred and ten day-old chicks divided into 7 groups and each group having 30 chicks. Control group was fed on basal diet and $\mathrm{T}_{1}$ and $\mathrm{T}_{2}$ group were supplemented with $0.5 \%$ and $1 \%$ of tulsi leaf powder in the ration, respectively. Likewise, $\mathrm{G}_{1}$ and $\mathrm{G}_{2}$ group were supplemented with $0.5 \%$ and $1 \%$ of ginger powder in the ration, respectively. $\mathrm{T}_{1} \mathrm{G}_{1}$ and $\mathrm{T}_{2} \mathrm{G}_{2}$ treatment groups were supplemented with $0.5 \%$ and $1 \%$ of both herbs in combination, respectively. Approximately $5 \mathrm{ml}$ blood sample was collected aseptically from wing vein of six randomly selected birds from each group at $42^{\text {nd }}$ day of experiment for haemato-biochemistry. Highly significant $(\mathrm{P}<0.01)$ effect of tulsi leaf and ginger powder was observed on $\mathrm{Hb}, \mathrm{PCV}, \mathrm{TEC}$, TLC, total protein, AST and ALT at $42^{\text {nd }}$ day of age. Serum albumin was significantly $(\mathrm{P}<0.05)$ increased in treatment groups $\mathrm{G}_{2}$ and $\mathrm{T}_{2} \mathrm{G}_{2}$. The serum glucose and triglyceride level was significantly $(\mathrm{P}<0.01)$ reduced in all treatment groups except $T_{2}$ as compared to control group. Highest reduction in cholesterol level was observed in $T_{2} G_{2}$ group which showed non-significant difference with $G_{2}$ and $T_{1} G_{1}$ group as compared to control and other treatment groups. However, creatinine and globulin showed non-significant difference among the treatment group. It may be concluded that supplementation tulsi leaf and ginger powder as feed additives improves haemato-biochemical parameters of broiler chicks.
\end{abstract}

\section{HIGHLIGHTS}

(0 Supplementation of tulsi leaf and ginger powder @ $0.5 \%$ each significantly improved haematological parameters of broilers.

○ Tulsi and ginger powder supplementation @ 0.5\% each improved serum biochemistry of broilers.

Keywords: Tulsi, ginger, haemato-biochemical, broiler

For many years, antibiotic growth promoters in livestock and poultry production have been practicing to promote growth and improve feed efficiency, thereby improving animal and bird health. However, the use of these feed additives not only raises the cost of production but also raises the growth of resistant microbes and produces residues in meat and eggs (Sojoudi et al., 2012; Yang et al., 2009). In the current situation, the use of in - feed- antibiotics is under threat after the ban of the antibiotic use by the European Union since January 2006. This ban has increased the prevalence of resistance to antibiotics in chicken (Kabir, 2009) and escalated the search for

How to cite this article: Shende, K., Dhuria, R.K., Goklaney, D. and Barolia, Y.K. (2020). Effect of tulsi (Ocimum sanctum) leaf and ginger (Zingiber officinale) powder as feed additives on haemato-biochemica parameters of broiler chicks. J. Anim. Res., 10(6): 1057-1062. Source of Support: None; Conflict of Interest: None क क 
alternatives for use in the poultry industry (Janardhana et al., 2009). Hence, many International Institutions and organizations related to public health are showing deep concern to reduce the use of antibiotics in poultry (Gatne $e t$ al., 2010). World Health Organization (WHO) has started to give emphasis on the development and use of herbal products for the benefit of world population in viewing the limitations and ill effects of chemical drugs (Jinsuklee, 2004). Currently natural alternatives like probiotics, prebiotics, plant extracts and the essential oils are gaining importance as alternative supplement (Pirogozliev et al., 2008; Yang et al., 2008; Ayasan, 2013).

Tulsi has been found to protect organs and tissues against chemical stress from industrial pollutants and heavy metals, and physical stress from prolonged physical exertion, ischemia, physical restraint and exposure to cold and excessive noise. Tulsi has also been shown to counter metabolic stress through normalization of blood glucose, blood pressure and lipid levels, and psychological stress through positive effects on memory and cognitive function and through its anxiolytic and anti-depressant properties. Tulsi's broad-spectrum antimicrobial activity, which includes activity against a range of human and animal pathogens, suggests it can be used as a hand sanitizer, mouthwash and water purifier as well as in animal rearing (Cohen, 2014).

Ginger is a perennial plant commonly known as ginger and belongs to the family Zingiberaceae which are aromatic herbs with fleshy, tuberous or non-tuberous rhizomes and often have tuber bearing roots (Ke et al., 2000). Ginger may act as a pro-nutrient because of active ingredients that are present in it. In many countries it is widely used as a food condiment and as a medicinal herb (Chrubasik et al., 2005). The use of ginger as a substitute for antibiotic growth promoters is desirable in order to increase the productivity of poultry, increase the palatability of food, increase the use of nutrients, stimulate the appetite and increase the flow of gastric juice (Owen and Amakiri, 2012). The main important compounds in ginger are gingerol, gingerdiol and gingerdione which have the ability to stimulate enzymes of digestive system, affect the microbial activity and having antioxidative activity (Dieumou et al., 2009). Ginger supplementation improved antioxidant and broiler Chickens blood serum when used in broiler diets, (Zhang et al., 2009).
The haematological component of the animal represents the physical tolerance of the animal to its internal and external environment (Esonu et al., 2001); it is important for the diagnosis of pathogenic and metabolic disorders and is a precious factor for assessing the health status of the person or flock. Changes in haematological parameters are also used to assess the effects of stress or toxicity due to environmental, nutritional or other factors. Normal ranges of haematological parameters may be altered by the consumption of plant constituents like Ginger (Ajagbonna et al., 1999). Therefore, the current study was conducted to assess the effect of tulsi leaf and ginger root powder on haemato-biochemical parameters of broilers.

\section{MATERIALS AND METHODS}

Two hundred and ten day-old, unsexed, apparently healthy broiler chicks (Cob-400 strain) procured from commercial hatchery were divided into 7 groups and each group of 30 chicks was subdivided into three subgroups having 10 chicks each. Routine vaccination against Ranikhet disease (F1 strain) and Infectious Bursal Disease were carried out on $7^{\text {th }}$ and $14^{\text {th }}$ day of procurement of chicks. Commercially available readymade broiler starter and broiler finisher rations were procured and feed additives such as Ocimum sanctum (Tulsi) and Zingiber officinale (Ginger) were supplemented. The experimental feed will be analyzed for proximate constituents by procedures of AOAC (2016). Control group was fed on basal diet and $\mathrm{T}_{1}$ and $\mathrm{T}_{2}$ treatment group were supplemented with $0.5 \%$ and $1 \%$ of Tulsi leaf herb in the experimental broiler starter and finisher ration, respectively. Likewise, $G_{1}$ and $\mathrm{G}_{2}$ treatment group were supplemented with $0.5 \%$ and $1 \%$ of Ginger herb in the experimental broiler starter and finisher ration, respectively. $\mathrm{T}_{1} \mathrm{G}_{1}$ and $\mathrm{T}_{2} \mathrm{G}_{2}$ treatment groups were supplemented with $0.5 \%$ and $1 \%$ of both herbs in combination, respectively. Approximately 5 $\mathrm{ml}$ blood samples were collected aseptically from wing vein of each of three randomly selected birds from each replication at $42^{\text {nd }}$ day of experiment for estimation of various hematological and serum biochemical parameters. Half of the blood was transferred to Ethylene Diamine Tetra Acetic acid (EDTA) containing tubes for estimation of hemoglobin, packed cell volume, total erythrocyte count and total leucocyte count. The remaining blood sample was transferred to non EDTA tubes for preparation of serum. Subsequently, serum was extracted through 
centrifugation of sample at $3000 \mathrm{rpm}$ for 15 minutes and stored at $-20^{\circ} \mathrm{C}$ until further analysis. Haemoglobin and packed cell volume were determined by Sahli-Hellige haemo-globinometer and micro-haematocrit method respectively. Total erythrocyte count and total leucocyte count were carried out manually through haemocytometer as per standard method of Benjamin (1978). Serum sample were tested for serum glucose, serum protein, serum albumin, serum triglyceride, cholesterol, serum alanine transaminase, serum aspartate transaminase, serum creatinine through semi-automatic haemo analyzer, using commercial test kits as per protocol procedure. The serum globulin content was determined from total protein levels by subtracting the serum albumin concentration.

\section{Statistical analysis}

Data collected during the current research work was subjected to statistical analysis by implementing standard methods of variance analysis as defined by statistical package for social science (SPSS), version 20. Significance of mean differences (F-values) was calculated by Dunken's multiple-range test as updated by Kramer (1956).

\section{RESULTS AND DISCUSSION}

The results of haemato-biochemical parameter of six week old broiler chicks are presented in Table 1. The statistical analysis of data revealed highly significant $(\mathrm{P}<0.01)$ effect of incorporation of herbs on haemato-biochemical parameter of broiler.

Highly significant $(\mathrm{P}<0.01)$ effect was observed on blood haemoglobin, packed cell volume and total erythrocyte count and significant effect $(\mathrm{P}<0.05)$ on total leucocyte count among the treatment groups as compared to control group. Highest haemoglobin was observed in $\mathrm{T}_{2} \mathrm{G}_{2}$ treatment group which was comparable with $\mathrm{T}_{1} \mathrm{G}_{1}$ group and $\mathrm{T}_{1}$ and $\mathrm{T}_{2}$ group. However, lowest haemoglobin level was observed in control group, which showed nonsignificant difference with $\mathrm{G}_{1}$ and $\mathrm{G}_{2}$ group.

Highest packed cell volume was observed in $T_{2} G_{2}$ group, which was comparable with treatment group $\mathrm{G}_{1}, \mathrm{G}_{2}$ and $\mathrm{T}_{1} \mathrm{G}_{1}$. In the control group, the lowest level of packed cell volume was observed, which was comparable with the $T_{1}$ group in statistical terms. Highest total erythrocyte count was observed in $\mathrm{T}_{2} \mathrm{G}_{2}$ group, which was comparable with treatment group $\mathrm{G}_{2}$ and the lowest level of total erythrocyte count was recorded in control group. Highest total leucocyte count recorded in $\mathrm{T}_{2} \mathrm{G}_{2}$ group, which was non-significantly differed with $\mathrm{G}_{2}$ group however the lowest level of total leucocyte count was observed in the control group which showed non-significant difference with rest of treatment groups except $\mathrm{T}_{2} \mathrm{G}_{2}$ group. This indicated that dietary supplementation of tulsi leaf, ginger and their combination might have positive influence on haematological parameter. The normal PCV, Hb, RBC and WBC depict the nutritional profile of the broiler chicken,

Table 1: Effect of supplementation of tulsi and ginger alone and in combination on haemato-biochemical parameters of broiler chicks

\begin{tabular}{|c|c|c|c|c|c|c|c|c|}
\hline \multirow{2}{*}{ Parameters } & \multicolumn{7}{|c|}{ Treatment groups } & \multirow[b]{2}{*}{ SEM } \\
\hline & $\mathbf{C}$ & $\mathbf{T}_{1}$ & $\mathbf{T}_{2}$ & $\mathrm{G}_{1}$ & $\mathbf{G}_{2}$ & $\mathbf{T}_{1} \mathbf{G}_{1}$ & $\mathbf{T}_{2} \mathbf{G}_{2}$ & \\
\hline $\mathrm{Hb}(\mathrm{g} \%)$ & $10.78^{\mathrm{a}}$ & $12.91^{\mathrm{b}}$ & $13.00^{\mathrm{b}}$ & $11.26^{\mathrm{a}}$ & $11.56^{\mathrm{a}}$ & $12.98^{\mathrm{b}}$ & $13.78^{b}$ & 0.45 \\
\hline PCV $(\%)$ & $29.28^{\mathrm{a}}$ & $30.78^{\mathrm{ab}}$ & $31.89^{\mathrm{bc}}$ & $32.28^{\mathrm{bcd}}$ & $33.56^{\mathrm{cd}}$ & $33.84^{\mathrm{cd}}$ & $34.17^{\mathrm{d}}$ & 0.68 \\
\hline $\operatorname{TEC}\left(10^{6} / \mu 1\right)$ & $2.66^{\mathrm{a}}$ & $3.32^{\mathrm{b}}$ & $3.40^{\mathrm{b}}$ & $3.43^{\mathrm{b}}$ & $3.99^{\mathrm{cd}}$ & $3.53^{\mathrm{bc}}$ & $4.09^{\mathrm{d}}$ & 0.20 \\
\hline $\operatorname{TLC}\left(10^{3} / \mathrm{cumm}\right)$ & $20.67^{\mathrm{a}}$ & $21.00^{\mathrm{a}}$ & $21.23^{\mathrm{a}}$ & $21.67^{\mathrm{a}}$ & $22.12^{\mathrm{ab}}$ & $21.34^{\mathrm{a}}$ & $23.89^{\mathrm{b}}$ & 0.77 \\
\hline Total protein $(\mathrm{g} / \mathrm{dl})$ & $3.99^{\mathrm{a}}$ & $4.08^{\mathrm{ab}}$ & $4.22^{\mathrm{b}}$ & $4.12^{\mathrm{ab}}$ & $4.20^{\mathrm{b}}$ & $4.39^{c}$ & $4.42^{\mathrm{c}}$ & 0.06 \\
\hline Albumin $(\mathrm{g} / \mathrm{dl})$ & $1.82^{\mathrm{a}}$ & $1.86^{\mathrm{ab}}$ & $1.89^{\mathrm{abc}}$ & $1.83^{\mathrm{abc}}$ & $1.98^{\mathrm{bc}}$ & $1.95^{\mathrm{abc}}$ & $2.00^{\mathrm{c}}$ & 0.04 \\
\hline Globulin (g/dl) & 2.17 & 2.22 & 2.33 & 2.29 & 2.22 & 2.44 & 2.42 & 0.07 \\
\hline Glucose (mg/dl) & $184.23^{\mathrm{e}}$ & $170.34^{\mathrm{bc}}$ & $179.34^{\mathrm{de}}$ & $176.56^{\mathrm{cd}}$ & $168.45^{b}$ & $175.23^{\mathrm{bcd}}$ & $161.34^{\mathrm{a}}$ & 2.48 \\
\hline Triglyceride $(\mathrm{mg} / \mathrm{dl})$ & $94.00^{c}$ & $86.58^{\mathrm{ab}}$ & $91.56^{\mathrm{bc}}$ & $84.94^{\mathrm{a}}$ & $82.55^{\mathrm{a}}$ & $87.12^{\mathrm{ab}}$ & $81.77^{\mathrm{a}}$ & 2.00 \\
\hline Cholesterol (mg/dl) & $201.12^{\mathrm{c}}$ & $196.12^{b c}$ & $191.29^{b c}$ & $189.68^{\mathrm{b}}$ & $172.95^{\mathrm{a}}$ & $174.18^{\mathrm{a}}$ & $167.15^{\mathrm{a}}$ & 3.34 \\
\hline $\operatorname{AST}(\mathrm{U} / \mathrm{L})$ & $231.30^{c}$ & $230.40^{\mathrm{c}}$ & $228.93^{c}$ & $220.44^{b}$ & $212.83^{\mathrm{a}}$ & $215.06^{\mathrm{ab}}$ & $211.73^{b}$ & 2.18 \\
\hline $\operatorname{ALT}(\mathrm{U} / \mathrm{L})$ & $21.83^{\mathrm{d}}$ & $19.04^{\mathrm{c}}$ & $18.84^{\mathrm{c}}$ & $17.42^{\mathrm{bc}}$ & $8.72^{\mathrm{a}}$ & $16.48^{\mathrm{b}}$ & $8.37^{\mathrm{a}}$ & 0.74 \\
\hline Creatinine $(\mathrm{mg} / \mathrm{dl})$ & 0.32 & 0.29 & 0.32 & 0.31 & 0.29 & 0.31 & 0.28 & 0.01 \\
\hline
\end{tabular}

Note: The means bearing different superscript in a column differ significantly $(\mathrm{P}<0.05)$. 
showing adequate nutrition of the chicks (Church et al., 1984).

Total protein and albumin content were significantly increase treatment group $\mathrm{T}_{2} \mathrm{G}_{2}$ group as compared to control group. However globulin content showed nonsignificant difference among the treatment group.

The Glucose content is significantly $(\mathrm{P}<0.01)$ reduced in all treatment groups except control and $\mathrm{G}_{1}$ group and highest reduction was observed in $\mathrm{T}_{2} \mathrm{G}_{2}$ group. The highest reduction of triglyceride content was observed in $T_{2} G_{2}$ group which showed non-significant difference with rest of groups except control and $\mathrm{T}_{2}$ group. The cholesterol content was significantly $(\mathrm{P}<0.01)$ reduced in $\mathrm{T}_{2} \mathrm{G}_{2}$ group which was comparable with $\mathrm{G}_{2}$ and $\mathrm{T}_{1} \mathrm{G}_{1}$ group and highest cholesterol content was observed in control group which showed non-significant difference with $T_{1}$ and $T_{2}$ group. Significant $(\mathrm{P}<0.01)$ effect was observed on ALT and AST content of blood due to tulsi leaf and ginger supplementation and highest reduction was observed in $\mathrm{T}_{2} \mathrm{G}_{2}$ group. Analysis of variance showed the nonsignificant effect on creatinine within the normal range.

The findings of present study are in accordance with Muthusamy et al. (2017) also reported significant $(\mathrm{P}<0.05)$ increase in the haemoglobin, packed cell volume, total erythrocyte count and total leucocyte count, albumin and total protein of layers in the treatment group supplemented with a blended herbal preparation (Ocimum sanctum, Zingiber officinale, Allium sativum, Trigonella foenum graceum and Curcuma longa)@0.25 and 0.5\% in basal feed as compared to control group. Oleforuh-Okoleh et al. (2015) also observed significant increase $(\mathrm{P}<0.05)$ in the haemoglobin, packed cell volume, total erythrocyte count and total leucocyte count of chicks fed on garlic and ginger infusion@50 ml/litre in drinking water as compared to control. Significant $(\mathrm{P}<0.05)$ increase in haemoglobin and total erythrocyte count also reported by Jadhav (2016) with supplementation of turmeric and ginger @ 0.5\% each as compared to control. Shewita and Taha (2018) investigated a significant increase in total serum protein (TP) in the $\mathrm{G}_{4}$ group supplemented with ginger powder $6 \mathrm{~g} / \mathrm{kg}$ of feed compared to the other treatment and control. Non-significant increase in serum globulin well corroborate with findings from Saeid et al. (2010), who recorded serum globulin, did not significantly differ between the treatment groups fed aqueous ginger extract at concentrations of 0.4 and 0.6 per cent supplemented with drinking water respectively.
Muthusamy et al. (2017) who stated that a mixture of herbal preparation (Ocimum sanctum, Zingiber officinale, Allium sativum, Trigonella foenum graceum and Curcuma longa) significantly reduced the glucose level as compared to control at 0.1 per cent level. Singh et al. (2014) reported that dietary addition of tulsi have significant $(\mathrm{P}<0.01)$ effect on serum triglyceride level of broiler chicks when supplemented with 0.5 and 1.0 per cent of ration as compared to control and total cholesterol reduced significantly@1.0\% of tulsi leaf powder in ration. Significant effect of ginger powder observed on serum triglyceride and total cholesterol of broilers in the present study is in line with previous studies of Saeid et al. (2010), Bamidele and Adejumo (2012), Mohamed et al. (2012) and Singare et al. (2014). Jadhav (2016) also reported significant decrease in serum triglyceride level when broiler supplemented with ginger and turmeric alone and in combination@ $0.5 \%$ each as compared to control. Depression of cholesterol level in the treatment group compared to other groups might be due to inhibition of the active enzyme hepatic 3 hydroxy 3 methyl glutaryl coenzyme A (HMG COA) responsible for synthesis of cholesterol in the liver (Crowell, 1999).

Sahooetal. (2019) recorded significant $(\mathrm{P}<0.05)$ decrease in the serum AST and ALT levels of the experimental broiler chicks in the groups supplemented with ginger and turmeric powder alone and in combination of both $@$ 0.5 and 1.0 per cent of ration. These results indicated that tulsi leaf and ginger powder supplementations decreased serum liver leakage enzymes and may enhance liver functions via improving cell membrane permeability. The positive effects of tulsi leaf and ginger powder on liver functions could be due to its antimicrobial and antioxidant substances (Grashorn, 2010; Khan et al., 2012).

Results of the present study regarding non-significant effect on serum creatinine are in accordance with (Onu, 2010; Shanoon et al., 2012; EL-Matty et al., 2014; George et al., 2015).

\section{CONCLUSION}

It can be concluded that supplementation of the herbs tulsi (Ocimum sanctum) leaf and ginger (Zingiber officinale) powder as feed additives at $0.5 \%$ of both herbs could be important to improve haemato-biochemical parameters. The birds were found in a good health with no signs of 
anemia which revealed the valuable and significant effects of these herbs.

\section{REFERENCES}

Ajagbonna, O.P., Onifada, K.I. and Suleiman, U. 1999. Haematological and Biochemical Changes in Rat given Extract of Calatropis Procera. Sokoto J. Vet. Sci., 1(1): 36-42.

AOAC. 2016. Official method of analysis, $20^{\text {th }}$ Edn., Association of Official Analytical Chemists, Washington, D. C., USA.

Ayasan 2013. Effects of dietary inclusion of protexin (probiotic) on hatchability of Japanese quails. Indian J. Anim. Sci., 83(1): 78-81.

Bamidele, O. and Adejumo, I.O. 2012. Effect of garlic (Allium sativum l.) and ginger (Zingiber officinale roscoe) mixtures on performance characteristics and cholesterol profile of growing pullets. Int. J. Poult. Sci., 11(3): 217-220.

Benjamin, M.M. 1978. Outline of veterinary clinical pathology. $3^{\text {rd }} e d n$., The Iowa State University Press Ames. Iowa, USA.

Chrubasik, S., Pittler, M.H. and Roufogalis, B.D. 2005. Zingiber isrhizoma: A comprehensive review on the ginger effect and efficacy profiles. Phytomedicine. 12: 684-701.

Church, J.P., Judd, J.T., Yomg, C.W., Kebay, T.L. and Kim, W.W. 1984. Relationship among dietary constituents and specific serum clinical components of subjects eating self selected diets. Am. J. Clin. Nutr., 40: 1338-1344.

Cohen, M.M. 2014. Tulsi - Ocimum sanctum: A herb for all reasons. J. Ayurveda Integr. Med., 5(4): 251-259.

Crowell, P.L. 1999. Prevention and therapy of cancer by dietary monoterpenes. J. Nutr., 129: 775-778.

El-Maaty, A., Hayam, M.A., Rabie, M.H. and El-Khateeb, A.Y. 2014. Response of heat stressed broiler chicks to dietary supplementation with some commercial herbs. Asian $J$. Anim. Vet. Adv., 9: 743-755.

Esonu, B.O., Emenalum, O.O., Udedibie, A.B.I., Herbert, U., Ekpor, C.F., Okolie I. C. and Iheukwumere, F.C. 2001. Performance and Blood Chemistry of Weaner Pigs Fed Raw Mucuna (Velvet Bean). Trop. Anim. Health Prod., 4: 49-54.

Gatne, M.M., Patil, R., Ravikanth, K., Shivi, M. and Rekle, D.S. 2010. Evaluation of immunomodulatory effect of Stresroak premix in broiler chick. Vet. World, 3(3): 122-125.

George, O.S., Kaegon, S.G. and Igbokwe, A.A. 2013. Effects of graded levels of ginger (Zingiber officinale) meal as feed additive on growth performance characteristics of broiler chicks. Int. J. Sci. Res., 4(3): 805-808.

Grashorn, M.A. 2010. Use of phytobiotics in broiler Nutrition - an alternative to infeed antibiotics? J. Anim. Feed Sci., 19: 319-328.
Jadhav 2016. Effect of supplementation of turmeric (Curcuma longa) and ginger (Zingiber officinale) powder on performance of broiler chicks. M. V. Sc. thesis submitted to Maharashtra Animal and Fishery Sciences University, Nagpur.

Janardhana, V., Broadway, M.M., Bruce, M.P., Lowenthal, J.W., Geier, M.S., Hughes, R.J. and Bean, A.G.D. 2009. Prebiotics modulate immune responses in the gut associated lymphoid tissues of chickens. J. Nutr., 139(7): 1404-1409.

Jinsuklee 2004. Medicinal Plants. A powerful health aid, Science creative quarterly.http//www.seq.ubc.ca/medicinal-plantsapowerful-health-aid/, retrived on 15.04.13.

Kabir, S.M.L. 2009. The role of probiotics in the poultry industry. Int. J. Mol. Sci. 10(8): 3531-3546.

Ke, J., Delin, W. and Larsen, K. 2000. Zingiberaceae. Flora of China, 24: 322-377

Khan, R.U., Naz, S., Nikousefat, Z., Tufarelli, V., Javdani, M., Qureshi, M.S. and Laudadio, V. 2012. Potential applications of ginger (Zingiber officinale) in poultry diets. Worlds Poult. Sci. J., 68(2): 245-252.

Kramer, C.Y. 1956. Extension of multiple range tests to group means with unequal numbers of replications. Biometrics, 12: 307-310.

Mohamed A.B., Mohamed, A.M., Rubaee, A.I. and Jalil A.Q. 2012. Effect of ginger (Zingiber officinale) on performance and blood serum parameters of broiler. Int. J. Poult. Sci., 11(2): 143-146.

Muthusamy, S.P., Murthy, T.R.G.K. and Vijayanand, T. 2017. Effect of blend herbal supplement on haematology and serum biochemistry in commercial layer chicken. J. World Poult. Res., 7(2): 48-56.

Oleforuh-Okoleh, V.U., Ndofor-Foleng, H.M., Olorunleke, S.O. and Uguru, J.O. 2015. Evaluation of growth performance, haematological and serum biochemical response of broiler chickens to aqueous extract of ginger and garlic. J. Agric. Sci., 7(4): 167-173.

Onu, P.N. 2010. Evaluation of two herbal spices as feed additives for finisher broilers. Biotechnol. Anim. Husb., 26(5-6): 383392.

Owen, O. J and Amakiri 2012. Serological and Haematological Profile of Bitter Leaf (V. Amgdalina) Meal. Biocatal. Agric. Biotechnol. 1: 77-81.

Pirgozliev, V., Murphy, T.C., Owens, B, George, J and Mccann, M.E.E. 2008. Fumaric and sorbic acid as additives in broiler feed. Res. Vet. Sci., 84(3): 387-394.

Saeid, J.M., Arkan, B.M. and AlBaddy, M.A. 2010. Effect of aqueous extract of ginger (Zingiber officinale) on blood biochemistry parameters of broiler. Int. J. Poult. Sci., 9: 944947. 
Sahoo, N., Mishra, S.K., Swain, R.K., Acharya, Pattnaik, S., Sethy, K. and sahoo, 2019. Effect of turmeric and ginger supplementation on immunity, antioxidant, liver enzyme activity, gut bacterial load and histopathology of broilers. Indian J. Anim. Sci., 89(7): 774-779.

Shanoon, A.K., Jassim, M.S., Amin, Q.H. and Ezaddin, I.N. 2012. Effects of ginger (Zingiber officinale) oil on growth performance and microbial population of broiler Ross. Int. J. Poult. Sci.,11: 589-593.

Shewita, R.S. and Taha, A.E. 2018. Influence of dietary supplementation of ginger powder at different levels on growth performance, haematological profiles, slaughter traits and gut morphometry of broiler chickens. S. Afr. J. Anim. Sci., 48(6): 997-1008.

Singare, S.G. 2014. Effect of feeding ginger (Zingiber officinale) powder on performance of broiler chicken. M. V. Sc. thesis submitted to Maharashtra Animal and Fishery Sciences University, Nagpur.

Singh, A., Doley, P., Mishra, R. and Neeraj. 2014. Effect of feeding tulsi (Ocimum sanctum) leaf powder in diet of broilers for quality meat production. J. Agric. Sci., 4(8): 446448.
Sojoudi, M.R., Dadashbeiki, M. and Bouyeh, M. 2012. Effects of different levels of symbiotic TechnoMos on broiler performance. Res. Opin. Anim. Vet. Sci., 2(4): 243-248.

SPSS 2018. Statistical package for social sciences, version 20 Procedure and Facilities for Research. McGraw Hill Book Co., New York.

Yang, Y., Iji, P.A., Kocher, A., Thomson, E., Mikkelsen, L.L. and Chot, M. 2008. Effects of mannanoligosaccharide in broiler chicken diets on growth performance, energy utilization, nutrient digestibility and intestinal microflora. Br. Poult. Sci., 49: $186-194$

Yang, Y., Iji, P.A. and Choct, M. 2009. Dietary modulation of gut microflora in broiler chickens: a review of the role of six kinds of alternatives to in-feed antibiotics. Poult. Sci. J., 65: 97-114.

Zhang, G.F., Yang, Z.B., Wang, Y., Yang, W.R., Jiang, S.Z. and Gai, G.S. 2009. Effects of ginger root (Zingiber officinale) processed to different particle sizes on growth performance, antioxidant status and serum metabolites of broiler chickens. J. Poult. Sci., 88: 2159-2166. 